料

\title{
原子炻用黒鉛材料 (II)
}

\author{
園田晋 \\ （昭和電工株式会社中央研究所）
}
1. 緒
言
2. 減速材上反射材
3. 原子䏓用黒鉛の製造
(以上 1 月号渴載)

\section{4. 黒鉛の性塏}

原子哣用材料として黒鉛が注目されるようになつてか ら，その性質が詳細汇究明されはじめ，兹数年間化夥し い報交が発表され急速な進展をるせている。

炭素は原子価 4 の原子であつて，ダイヤモンドと黒銶 の2通りの固体を形成する.ダイヤモンドは一重結合に よつて 1 個のC 原子が 4 個のC 原子と結合し，C原子群 は正四面体格子を形成している。これは現在知られてい る内では最る硬い物質である。黒鉛柱物質中最も軟かい 部類に属するもので， 1 個のC 原子が 3 個のC原子と結 合して巨大な予子面を形成し，乙れ等の分子面同志は比 較的緩く結合し合い，後述の様な結晶をつくつている。

4 価のC原子が 4 個の結合手で强固䎲結合するのは当 然だが，3 個の結合手でるそれと同程度に結合し得る事 を，最初 Kekulé が二重結合の概念を用いて説明した が，後に量子力学の概念住よて巧みに説明できるよう になつた ${ }^{(18)}$.

黒鉛の特異な性質は，告の単結鼠子が大きな異方性を 示し，結晶間結合汇高分子的性質を示すとい52 つ0因 子が同時に存在する事が主な原因になつている。

黒鉛の結晶が允分大き発達していない炭素安微昆賀

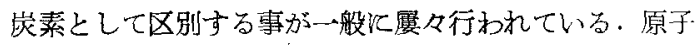
炬用と乙て炭素よりす黒鉛の方が使われるのは何故か之

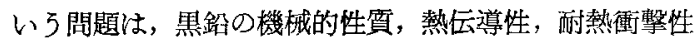
及び純度が秀れている事がその主な原囚である。

4.1 結晶構造黒鉛の結晶は 1 種の層格子であつ て，C原子の正六角形環の集合した網面が互に平行清 み重つている、網面炕和けるC原子は強力な等極結合に 上つて結付いているが，網面相互、骑い van der Waals 力化よつてつながつていると過をず，黒鉛の物理的諸性

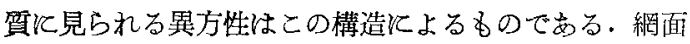

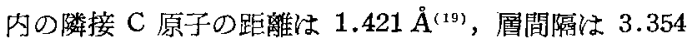
$\AA^{(20)}$ である、網面の積み重なりには幾分の自由度があ り，普通《見られるのは第 1 図江示すような網面 1 枚执
きに繰返しのある構造であるが，2枚括き亿繰返しのあ る構造との他も存在するといわれている(21)。前者を一 般化 Bernal 構造 ${ }^{(22)}$ 又心 $\mathrm{ABAB}$ 構造と云い, 後者を Debye-Scherrer 構造 ${ }^{(23)}$ 又は $\mathrm{ABCABC}$ 構造と呼ぶ。

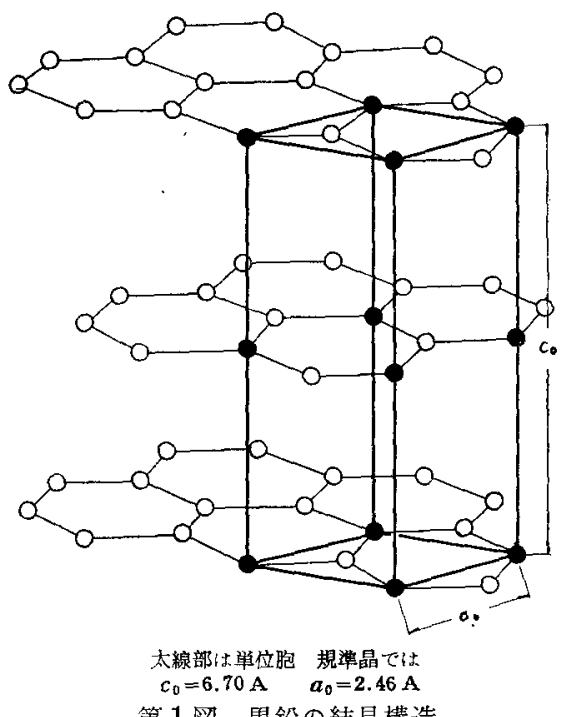

第 1 図黒鉛の結晶構造

以上は黒鉛の理想結晶についてであるが，所謂 “非結 晶質炭素”とい3のは網面相互の皘重なりと秩序的な配 位をるた乱周系 (turbostratic) 構造(24)であつて，普 通一般飞存在する黑鉛汇活者の中間として多少とす網 面の重なりと乱れをるつている. 古くU. Hofmann(25) 等もこの乱れを指摘したが，近時 R.E. Franklinn ${ }^{(26)}$ は この乱れの有様を次の様汇䇉明した. 即ら一般飞人造黑 鉛の平行網面群炕以理想黒鉛の様な網面の積重りを持つ 部分と, 非鼠質炭素の如き積重りをもつ部分とが, 統 計的汇無秩序に混在して呿り，前の部分での風間隔は $3.354 \AA$,後の部分でのとれは $3.44 \AA$ である. そして両 方の蔀分の境目の 1 層 ${ }^{(26)}$ 又は 2 層 ${ }^{(20)}$ の酋間隔だけが耐 者の影響をうけて中間的な值をとる。結晶化の進えだ黑 鉛では平行網面群中の理想的結晶部分の割合 (p) が80\% 
を越觉る。

少, 上の $\mathrm{ABCABC}$ 構造が黒鉛本来のものであるか とい5ことについて疑議も唱えられている(27).

4.2 熱力学的性質 昇華熱熱力学的江重要な值

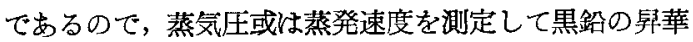
熱を求めよ5とする実験が数多く行われた ${ }^{(28)}$ が，未だ 確かな值が得られていない。しかし最近は $170.4 \mathrm{kcal}$ $\mathrm{mol}$ K一致しつ」ある.

一方, 炭素の蒸気压は低く $\left(2500^{\circ} \mathrm{C}\right.$ で約 $\left.5 \times 10^{-6} \mathrm{~atm}\right)$ それが $1 \mathrm{~atm}$ 飞達するのは $3600 \sim 3700^{\circ} \mathrm{C}$ である(29).

又三重点 $\left(4000^{\circ} \mathrm{K}\right)$ 飞括ける圧力は約 105 気圧といわ れ(20)ているから，融点を直接測定するととも困難であ る. 最近 National Carbon 会社の Jones ${ }^{(1)}$ \& $150 \mathrm{~atm}$ のアルゴン雰囲気中で弧光処理により黒鉛を熔融したと いうことである。

黒鉛の比熱は興味深い特性である. 常温以上では2.05 $\mathrm{cal} / \mathrm{g} \cdot \mathrm{atom} / \mathrm{deg}\left(300^{\circ} \mathrm{K}\right)$ から温度上昇とともに濑増して 約 $2000^{\circ} \mathrm{K}$ で Dulong-Putit の $6 \mathrm{cal} / \mathrm{g} \cdot$ atom $/ \mathrm{deg} K$ 近 づく (31) (第 2 図)，低温領域の，20 60\% で比熱は $T^{2}$ 飞比例して增加し ${ }^{(32)}, 1.5 \sim 10^{\circ} \mathrm{K}$ ては $T^{2.4}$ K比

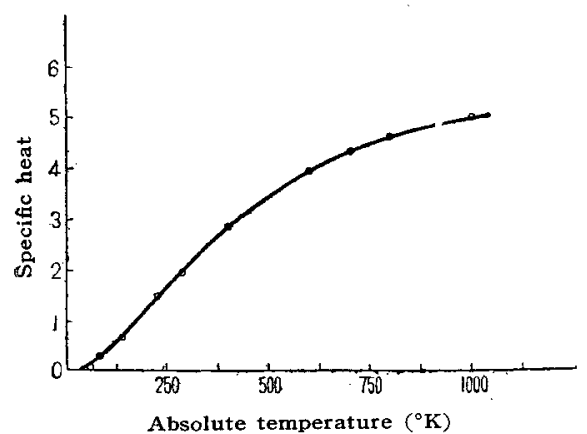

第 2 図 黒鉛の比熱 (Magnus-1923)

例するよ5飞見觉る（第 3 図)，これ関する理論は 大凡がかからただけで，詳 細とついては未だ諭議が続 いている( ${ }^{(33)}$.

比熱が低温飞於て $T^{2}$ V 比例する理由については， 黒鉛結晶のような異方性物 質の振動スペクトルを取扱 52 通りの方法から説明さ れている.1つは純䊉茷 何学的な考方方 (Krumhansl and Brooks $\left.{ }^{(3)}\right)$ で 2 次元系でスペクトルの近 似的特性から $C_{v}$ が $T^{2}$ V 比例するという Born-von Karmanの取扱を基にした

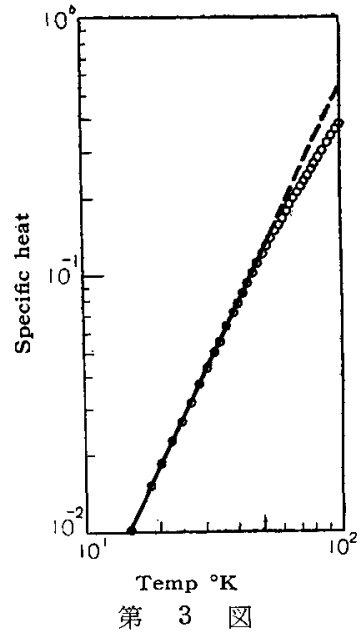

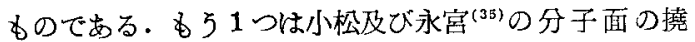

み振動としての面外振動の考察である. 無限固体の弾性 スペクトルの振動周波数を $f$, 波長を入とすると，伝播 速度 $v=f \lambda$ は本質的に一定てあるが，撓夕波に対して は $f \lambda^{2}=c$ となり, 群速度 $d f / d(1 / \lambda)$ は一定でなく $f^{0.5}$

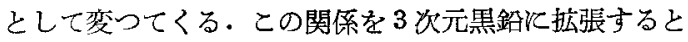
$C_{p}$ が $T^{2}$ 飞比例するという結論が導かれる。

この 2 っ見方は一致させる事が出来る.結合手の撓 みでは撓みのモードは最近傍の隣接同志の間強力な相 互作用を生し， plate-bending approximation K極め てよく似たスペクトルが現われるのである。従つて，先 の Krumhansl et al. ${ }^{(34)}$ の考方方於て Born-von Karman の式彷ベ゚ンの分子力常数を用いて計算す れば，比熱が $T^{2}$ 飞比例するという事は半定量的に了解 される(1)。

4.3 電氢的及び磁気的性犋電気的及び磁気的性 質の大势法 Wallace ${ }^{(36)}$, Coulson ${ }^{(37)}$, Barriol ${ }^{(38)}$ 等 ${ }^{(39)}$ 〜 (42)の報告によつて知ることが出来る. 固体黒鉛の土亦 ルギー準位とその電子密度とは電子の一部が結晶中を䮖 忛䞡ることができるようとなつていて，これが電気伝導 性の因をなしている。

Wallace 等性無限大单結晶とついて計算を行つてい る.電子ェネルギー帯構造(第 4 図) そ於て $0^{\circ} \mathrm{K}$ で電
棌電帯

去満带

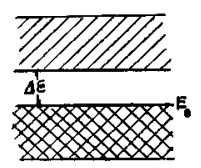

$0^{\circ} \mathrm{K}$ に於て

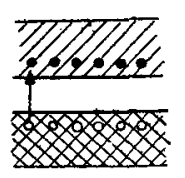

温度か上ると
子汭つて立 たされている 充満带と空い ている導電帯 とを隔てる禁 制带の幅 $\Delta \epsilon$ が狭く, 温度 が高くなると充満帯の電子はそこに正孔を残して導電带 に励起され，この電子と正孔がとす笛導江寄与するの であるが，Wallace によると Fermi の分布によつて許 容される自由電子の数は常温で $2.25 \times 10^{-3}$ 個であり従

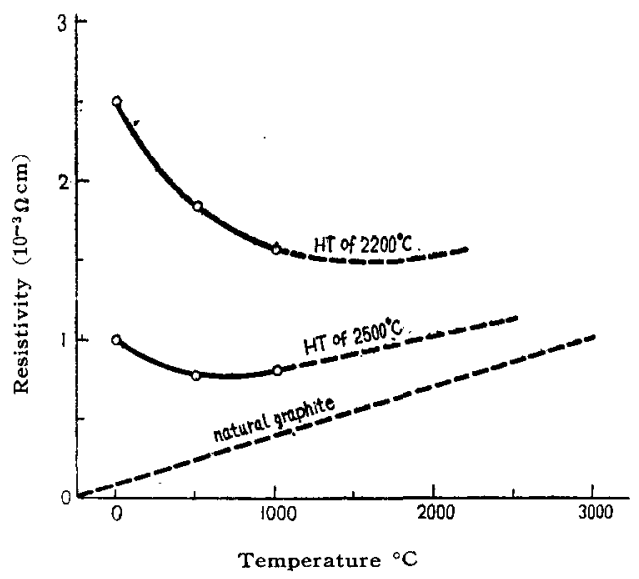

第 5 図黑鉛の比抵抗の温度変化 (HT は熟処理湜度) 
つて電気伝尊度は高くない，電導度はキャりヤ一の数比 よるばかりでなく，それが運動するときの散乱にも左存 される。一般原子の格子波に完全週期性加らの偏移が あると雷子は散乱し彷つて抵抗が増加する.そ心偏移の 原因の 1 つは原子の熱運動であつて温度上昇上ともに抵 抗を増すことになる. 天然黒鉛の電導度を春測した結果 によると，測定值は温度が下るに従い上昇するが，10

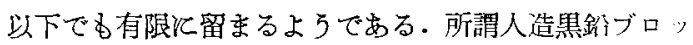
ク(多結晶黒鉛) では温度上昇上ともに少くとも $400^{\circ} \mathrm{C}$ までは電気抵抗が減少する. 石油コ一クスからつくつた 黒鉛では，熱処理温度にようて違うが，極小点は 400 $600^{\circ} \mathrm{C}$ に市り, 爾後電気抵抗は直線的に増加する（第 5 図)、乙の範囲に和ける人造黒鉛の举動管万格子振動 の優位性に㷌せられている。

Wallace の計算飞よると, 網面に平行方向 $(a)$ の留 導度は垂直方向（c）の110倍である.ところが佘测 值では $10^{2} \sim 10^{5}$ 倍であり，異方性が甚しく現われる。

Pinnick ${ }^{(4)}$ は有機物党炭化して生ずる炭素を加熱し 温度を上昇して遂化 $2500^{\circ} \mathrm{C}$ 以上飞到らしぬ多結晶黒釗 化する過程に於て, 熱処理温度の函数としての電気抵 抗, Hall 係数 ${ }^{(45)}$ 及び熱起電力 ${ }^{(46)}$ の変化を電子諭的に 考察した興味深い報告をしている。

前に述べた電子エネルギー带構造の考方方からすれば 䋘粋な黒鉛では，正孔と電子との数が等しいことにな り，又雨者の易動度が等しければ耐者が打消し合つて Hall 係数零となる䇢である゙.ところが実際には純粋 な人造黒欽，天然黒鉛の Hall 係数は負であつて，従つ て電子の方が正孔より僅か動き易いといらことがわか る.

磁気的性質は炭素の電子諭的挙動研究するも510 の方法を与党るものであり，それが散乱には無関係であ るから，又違つた情報を与える等である。

常温に扎ける diamagnetic susceptibility そついて 2,3 の研究報告がめるが(47) (49)，各研究者の值がよ く一致している.第6図に代表的な結果を揭げる。

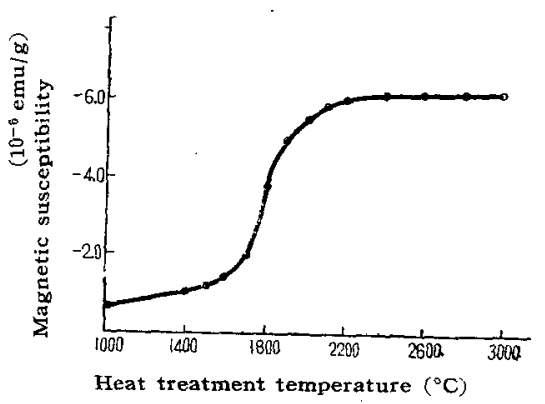

第 6 図 熱処理温度による帯磁率の変化

磁気係数 $(x)$ が微結晶の-0.5 $\times 10^{-6}$ 加ら巨結晶の $-6.0 \times 10^{-6}$ K上暑乙それ以上の大きな寸法の結晶に対 して一定となつているが，現在のとこる炭素の反磁性理
論がその飽和現象を明快に説明し得るまてには到つてい ない，黒鉛の $x$ が異常に高いのは，さきの带構造に於 て带の端部には有效な電子や正孔の分布が少いことに由 来すると考劣られている， $\chi$ の理論值及び実测值に特い ても大きな異方性か見られる。

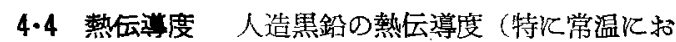
ける）は極めて大きく，粒子に平行な方向ではアルるニ ウムに相当し，垂直方向では真鍮に近い。

黑鉛の熱伝導度に関しては Powell and Schofield(50), Berman ${ }^{(51)}$, 水島 ${ }^{(52)}$, Tyler and Wilson ${ }^{(53)}$, Smith ${ }^{(54)}$, Castle ${ }^{(55)}$ 等の研究がある.

Berman (51) は天然黒銷の単結晶について，網面に平 行仪び垂直の雨方向に熱伍導度を測定して第 7 図の如き

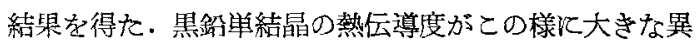
方性を示すこ と加ら，多結 鼠体の場合に 坆導される 爇の大部分は 各結罚子の網 面沿つて流 れると考觉て よいである 5. 多結楽墨 雏の熱伝導度 と温度との閔 係第 8 図K

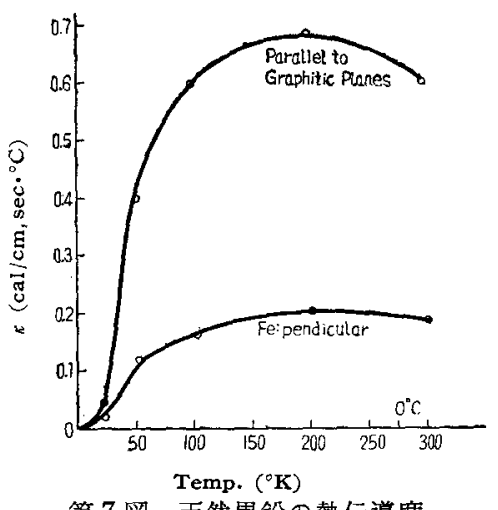

第 7 図天然黒鉛の熱伝導度 (Berman 1952) 示寸。

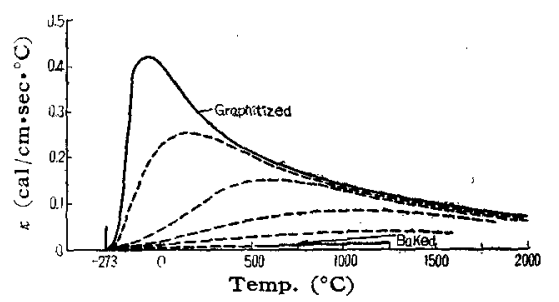

第 8 図多結晶黑鉛の熱伝導度と温度との関係

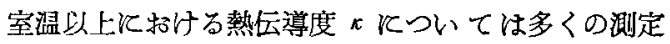
がなされている. Lorentz, Wiedemann-Franz の比 （電気抵抗と熱伝導度との皘を絶対温度で割つた値）が 温度仙より一定でないととから，黒鉛の熱云導は金属の

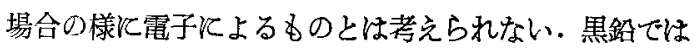
熱エネルギーは結晶の格子振動炕よて后播するのであ る・格子振動汇よる熱伝導度の関保山次式で示される。

$$
x=r C v L
$$

ただし $r$ : 幾何学的因子（等方物貧では 1/3）

$C:$ 結晶比熱

$L:$ 振動波の平均自由行程

$v$ : 振動波の伝播速度

さて前揭の第 8 図に於て実線で示した黒鉛の熱云導度 
対温度曲線に注目しょ5。高温部に於ては，さきに比熱 の項で述べたよ 5 に，比熱C は略々一定の值をすつ. 又 温度上昇ととも《原子の熱運動が激しくなつて $L$ が減 少する.その結果, 温度上昇ととすに熱后導度が娍少す るととになる。

低温部に於ては，振動波は散乱を受けることなく結晶 中を凡ゆる方向に移動することができ，結晶の粒界によ つて散乱されると考兄られるから，Lは絓晶子寸法に近 いるのと考学てよいであう. 更飞格子欠宿（転位）及 び不純物などが振動波を散乱するだけだとすると熱伝導 度は主に比熱Cに左右されることになるから，低温に拓 ける熱层導度は比熱と同様の温度依存性を持つべきであ

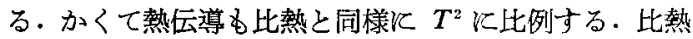
が極限值澾すれば，てとにピークを残して曲線は高温 飞向つて低下を示す・ピークの高さは結晶子寸法に比例 する.

Johnson ${ }^{(1)}$, Micinski $^{(1)}$, Neubert ${ }^{(1)}$ 等沉よると熱伝 尊度 $\kappa\left(\mathrm{cal} / \mathrm{sec} \cdot \mathrm{cm} \cdot{ }^{\circ} \mathrm{C}\right)$ と電気比抵抗 $\rho(\Omega \cdot \mathrm{cm})$ との 積は一定である。

$$
\kappa \rho=0.00031 \pm 0.00001 \quad\left(25^{\circ} \mathrm{C}\right)
$$

簡単飞測定できる $\rho$ から上の式とより $た$ を求めると 5 $\%$ の籁围で測定值飞一致する。

4 -5 熱膨脹 黒鉛䊅晶の熱膨脹には極めて大きな異 方性が見られる. Nelson and Riley $^{(56)}$ は粉䂶したセイ ロン黒鉛（灰分 $4 \%$ ）の熱膨脹を高温X線カメラを用い

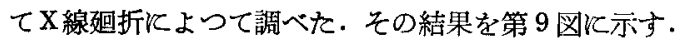

$a$ - 方向の熱膨脹 係数は原子価結合加 ら期待されるよ 5 K 非常飞小さく, 低温 では負の值を示し約 $383^{\circ} \mathrm{C}$ 飞於て符号を かえる、これは原子 振動の性筫が変るこ とによるものであ る. 低温 $\left(<100^{\circ} \mathrm{C}\right)$ では熱エネルギーは ベンゼン環構 造の結合距離 を拡げること なしに炭素原 子を網平面外 一振動 $(c$ 方 向）せしめる から平面の収 縮をきたす結 果になる・温

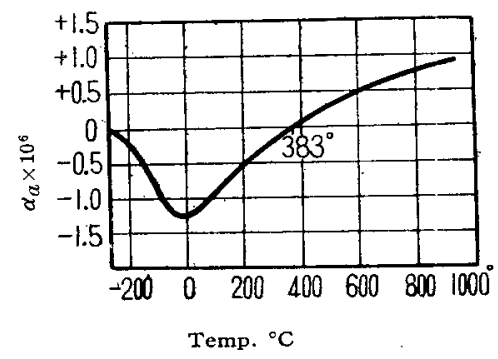

第9四照鉛結晶の熱膨脹 (Nelson \& Riley)
度が上昇して網平面内の振動が熱エネルギーに寄言しは
ごめると傾向は反転し結晶平面は膨脤し始める ${ }^{(57)}$.

Walker, Mekinstry \& Wright(58) は純䊀な石油コ一 クスでつくつた黒鈶について $-196^{\circ} \mathrm{C} \sim 1118^{\circ} \mathrm{C}$ で周間 淂を測定して $c$ 軸方向の膨脹係数として $28.6 \times 10^{-6} /{ }^{\circ} \mathrm{C}$ 在得たが，これは Riley 等の值とよく一致している. Bowman ${ }^{(1)}$ 火よると $2000^{\circ} \mathrm{C}$ 烧成と $3000^{\circ} \mathrm{C}$ 焼成の6の を比較したが $c$ 軸方向の熱膨脹には差を認めなかつた.

単結晶の熱䏽脹と製品の見掛けの熱膨脹との関係は 2 次的なものである. Nelson \& Riley は結晶の体膨脹係 数を $25.3 \times 10^{-6} /{ }^{\circ} \mathrm{C}$ と計算しているが, Bowman が黒 鎑製品とついて互值角な方向の膨脹係数を測りとれか 占体膨脹係数を算出した結果は $3000^{\circ} \mathrm{C}$ 烧成品で $5.6 \times$

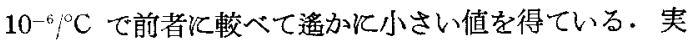
際の下.業製品についての測定値は前浲造法の節で示し た数表を参照されたい，第 10 図は Westbrook \& Mi$\operatorname{cinski}^{(n)}$ が, 種々の黒鉛飞ついて押出方向に平行に試 片をとつて，熱膨脹係数の温度変化を測定した結果であ る.これとよると，各試料で不規則な膨脤が見られると

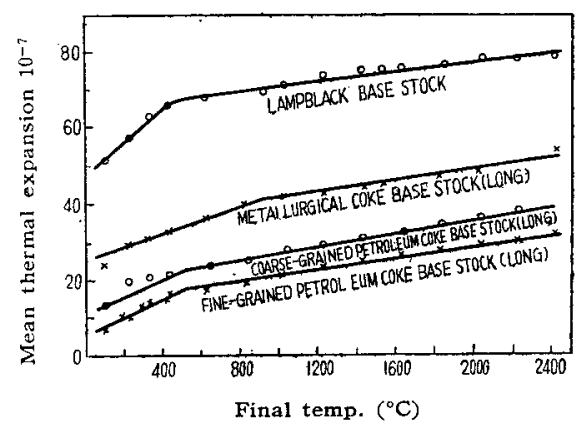

第 10 図熱膨脹の温度変化 (押出方向に平行)

ころもあるが，大体の形は似て括り熱膨脹俰数の温度変 化恪々等しいと考学られる。

4.6 輻射能 黒鉛は高温で使用される事が多く，高 温では熱が対流上り輻射で失われる事が多いから，輻射 能の問題も重要である。高温飞挌ける測定では一般とを 5であるが，輻射能の測定值は測定者により差が大き い. 更に黒鉛の輻射能は表面の仕上状態によつて変り， 又はじめによく磨かれていてる高温で長時間加熱される と表面状態が変つてきて輻射能が増加する. Thorn \& Simpson ${ }^{(59)}$ そよると黒鉛の輻射能は $0.75 \sim 0.90$ であ つて，正確な值は表面状態䏓よて幾分変動する。

$4 \cdot 7$ 機械的性質 黒鉛はその風間力が弱いので凰面 に沿つて方りやすい，然しこの过りは結晶転位を動なす ことはないようである．黒鉛の閏滑性はこの过り易さの ためであるとされているが Savage ${ }^{(60)}$ は水，アンモニ ア，炭化水素等の财着層の存在が必要である事を指摘し ている.

奏用の黒鉛製品はその成型工程に执いて選択的配位を 
与亮られ，従つて強度は異方性をるつ．その異方性は型 込式成型品江於て最手甚しい，黒鉛恃特强度の大なる 物頶てはないが，酸素のない高温で有用な構造材です 名、黒鉛の強度以温度とともに $2400^{\circ} \mathrm{C}$ 以上まで增杊す る. $1600^{\circ} \mathrm{C}$ 以上の温度で黒鉛より強い物質はない。これ は貴重な特性である。

Mrozowski ${ }^{(57)(61)}$ 亿よると炭素の構造他由来与る大き

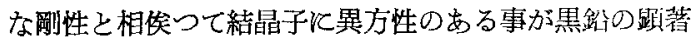

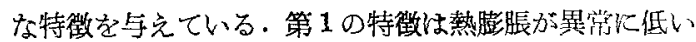
事とその変動が広い事 (各種炭素に対して) 並びに構篮 鋭感性（structure sensitiveness）が大きい事である。 第 2 常温次称いて炭素は避け得られない結昆閒気孔を もつことである. 単結晶の蒿膨脹と多結晶の蓠膨脤とつ 差によって，炭素が高温度から冷却された時《生ずるる のである.第 3 は前の 2 者と密接な関係があるのだが， 黒銔材料中江不可避的に残留寸る凍結応力 (Frozen-in

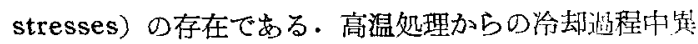
方性収縮によつて生じた内部応力は，金属の場令のよう そ結晶粒界の粘性流動によつて局部的飞軽減される事が 少いので材料中閂でこめられて残留し，再び加熱する ことによつてのみ緩和するととができる。のよ5な施 力倲結の存在が黒鉛の機械的強度の独特な温度從属性の 原因である。

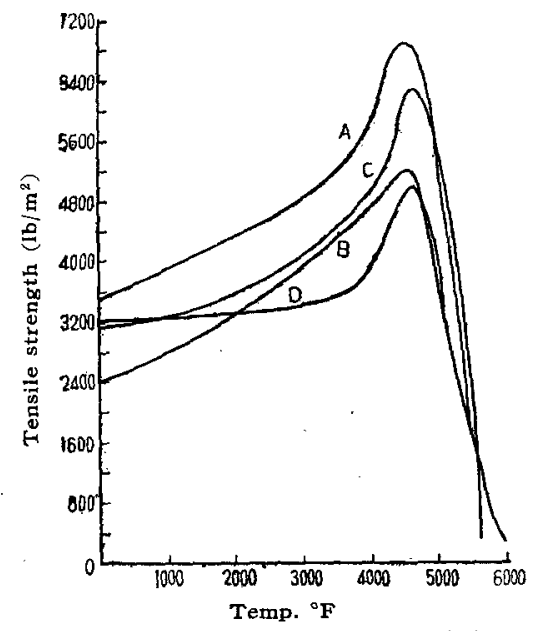

A Commercial graphite, electrode (ECA) // to extr. density 1.67

B Commercial graphite,block (C-18) \& \& // to extr. 1.60

C Commercial carbon, block (SA-25) $\perp$ to mold 1.67
D Commercial graphite, block

第 11 図各種黑鉛の抗張力飞対する温度の影響 (Udy \& Boulger)

第 11 図 ${ }^{(62)}$ は黒鉛の機械的強度と温度との関係を示 す. 強度は約 $2500^{\circ} \mathrm{C}$ まて温度と共に 50 100\% 增加

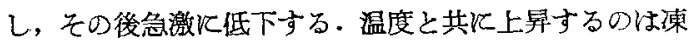
結応力が徐々に綬和するためである。塑性変形を経て破 断が起るに到れ代降下が現われる。

実際の黒雓製品ではその製造法からる予測されること てあるが，之の機珹的性質は，同し原料からの品物でる 䧕験片每江差があり，更に一本の武験片於ても，その 断面皘全体泚つて性䨘が一様ではない，大きな品物て

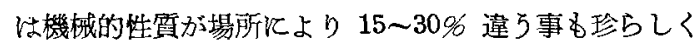

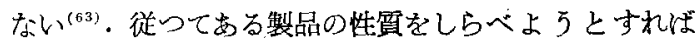
数多くの試験片についてデータをとらねばならない(1).

Malmstrom 等(62) そが，高温で注黑鉛も延伸性を持ち約 70\% の延伸率を 示す. $0.1 \%$ の伸びと搁るクリープ速度を $2300^{\circ} \mathrm{C}$ K 於て 2 時間週期とし，常温破断強度の $85 \%$ の負荷をか けて測定した. $2700^{\circ} \mathrm{C}$ で注, 常温破断強度の数960応 力で相当のタリープを起す（第 12 図）.

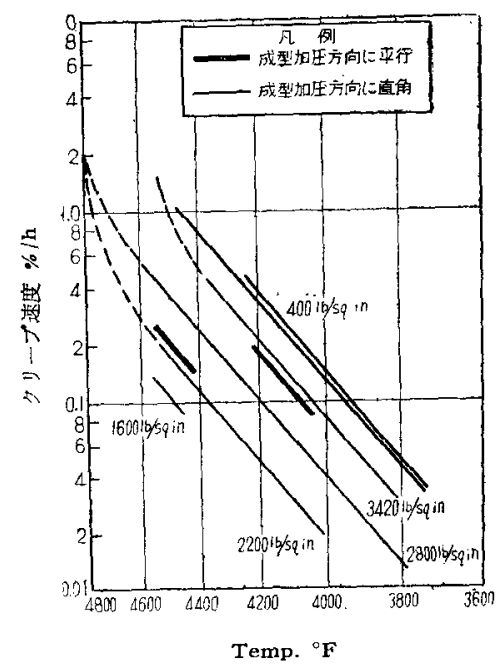

第 12 図 C-18 黒鉛のクリープ速度 ${ }^{(82)}$

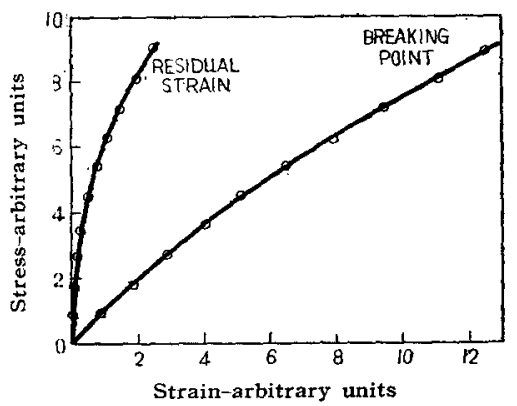

第 13 图 黒鐰の応力歪曲線温度
黒鉛の弹性 率怟低（圧 延した鉛之同 程度).そのた め渜熱衙撃 性が優れてい るのである。 Malmstrom 等 ${ }^{(62)}$ 江弹狌 湫は温度上舁 と共保僅加 万增加儿, $2000^{\circ} \mathrm{C}$ で注 常温より40\% 大きい之報告 している。

黒銛恃常温 でも完全㥳 は弹性的で なく，向幾 分の塑珄を ๖ってい る. 第 13 図は黒鉛の 屈曲刘す 当応力一霆 曲線であ る. 応力と 歪との関係㹥線的ではない，との測定で一回每江応 力を除きとの時の残留歪す測定している. 図の左側の曲 線がそれである。

4.8 化学的性質 黒鉛は他の元素や化合物と此でる と，化学反灾沉於て極めて不活性である. 然し黒銛は次 の 3 種の侵強受ける.酸化，風間化合物の生成，炭化 物を主生する金属との高温での反応がそれである。 


\section{(1) 酸 化}

高温に於ては, 酸素から防護され奴限り黑鋁は燃焼し て $\mathrm{CO}_{2}$ や $\mathrm{CO}$ になつてしまう。低温では黒釭は金属よ り酸化し難、物質なのだが，酸化物が揮発性なので保護 皮膜ができないし更に多孔質であるため酸素が侵入し易 く酸化面積が広いのである。

“Threashold 酸化温度”とい5のは $24 \mathrm{~h} て ゙ 1 \% 0$ 重量減を爕らす温度之定義されるるのであるが，黒鉛の それは 520 560 C である. 少量の触媒 ( $\mathrm{Na}, \mathrm{K}, \mathrm{V}, \mathrm{Cu}$ 等）を添加するとThreashold 酸化温度を低下し，低温 ての酸化速度を大とする事ができる。

Threashold 酸化温度より $200 \sim 250^{\circ} \mathrm{C}$ 高い温度まて は，酸化はまた唀的であつて容積減よりも重量減の方 が大きい，それ以上の高温では，酸化は昖散に支配され るよ5となり，凡て酸化は外側の表面で行われるよ5に なる、この温度範囲附近では, 酸化速度は表面に拝ける 空気の流速に対し極度に敏感になる ${ }^{(64)}$.

水蒸気や $\mathrm{CO}_{2}$ によつてる酸化が起るが, Threashold 酸化温度は水蒸気では $700^{\circ} \mathrm{C}, \mathrm{CO}_{2}$ で $900^{\circ} \mathrm{C}$ で空気 や酸素の場合上り稍々高い，酸化性溶液に上る湿式酸 化 ${ }^{(6)}$ の研究子沢山行われているがこ」では触れない。

(2) 層状化合物

黒鉛は層状化合物をつくり易い，首状化合物とい50

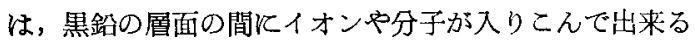
化合物で，その際層間隔は拡げられる．層状化合物がで きると黒鉛は崩壊し易くなる・との種の化合物の生成や 性質には理諭的な與味が深い、Hofmann ${ }^{(65)}$ や Riley ${ }^{(67)}$ らがよく研究している.

黒鉛の層状化合物は次の群份類される。

A) 酸化条件下で生成される黒鉛と酸との化合物 ${ }^{(f)(69)}$ (70)

B）黒鉛とハロゲン对含ハロゲン基との化合物 ${ }^{(7)(72)}$ (73) (74)

C）黒銷とアルカリ又はアルカリ土類金属との化合 物 ${ }^{(72)(75)(76)(77)}$

D）黑鉛と金属ハロゲン塩との化合物 ${ }^{(78)}$

(3) 炭化物の生成

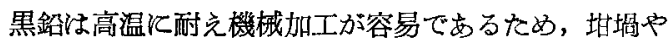
鋳型として使用され好ましい成績を収めてきた. 熱层導 がよいのでチル沉もよいし又連続鋳造のダイスにも適し ている.銅，真鍮，アルミ，マグネ，鋼の熔融，銶造に 量鉛は好適である。

治金用に黒鉛を使万際の制限は，多くの金属と黒鉛が 炭化物をつくつて合金してしまう事から来る。炭化物を つくりやすい金属は $\mathrm{Mo}, \mathrm{V}, \mathrm{Si}, \mathrm{Cr}, \mathrm{Ni}, \mathrm{Ti}, \mathrm{Zr}, \mathrm{B} な$ ぞである・但しこれ等に於ても坩堝としては充分使える 場合加多い。

液体金属による黒鉛の窗蝕汇は多くの研究がある。第 14 図は Liquid Metals Handbook に示されているも

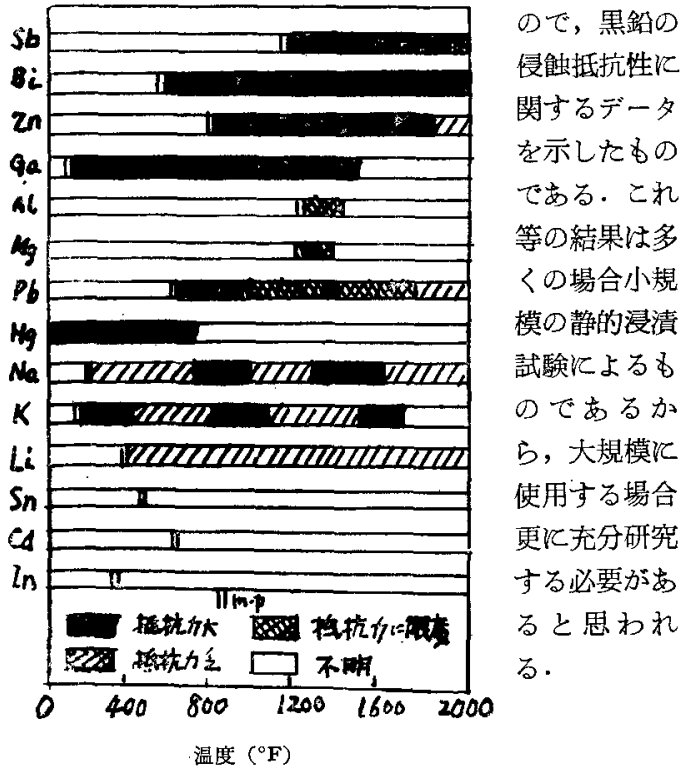

籍14図 液体金属による黒鉛の侵蝕

\section{5. 放射線照射障害}

ジュネーヴ会議に於て Woods, Bupp, Flacher ${ }^{(79)}$, G. R. Hennig ${ }^{(84)}$ 及び Kinchin ${ }^{(80)}$ 飞よつて可成り詳細 な報告が為された。

黒錄は原子炕中で放射線の照射を受けると結晶構造に 変化を受け物理的性䐝が変る。機械的強度は改善され硬 度も堌加する。然し他の物理的性筫は有害な作用を受け る. 即ち熱伝導度及び電気伝導度は減少し, 黒鉛形状に は寸法梁化が起る. 又ポテンシヤルエネルギー蓄積に遭 遇する・照射中黒鉛の温度が増せばそれぞれの影響の大 さは減少する。

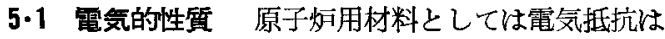
あまり重要な性質ではないが，電気抵抗の測定をすれば 障畫の度合を知る事ができ文理論的考察に都合がよい。 黒鈶中では電荷は電子と正孔の双方によつて運ばれるこ とは前にる述べた. 電気抵抗は電荷のキャりャーの濃度 と平均自由行路によつて決まる，照射を受けて生じた格 子欠宿は電子や正孔を散乱するから平均自由行路は短か

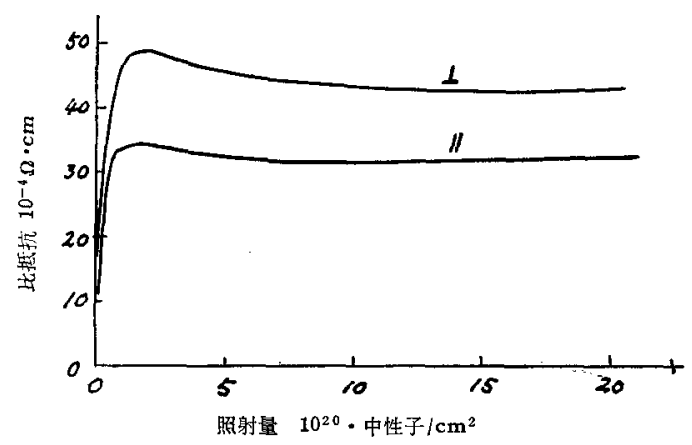

第 15 図中性子照射による黒鉛の電気比把抗 
くなる・第 15

図に示すよ5

に黒鉛の電気

抵抗は照射の

初期段階に急

激江変化す

る.その時

Hall 係数を

測定すると，

電子加格子欠

陥熘つてい

をことが解

る. 正孔の濃

度の増加と自

由電子の濃度

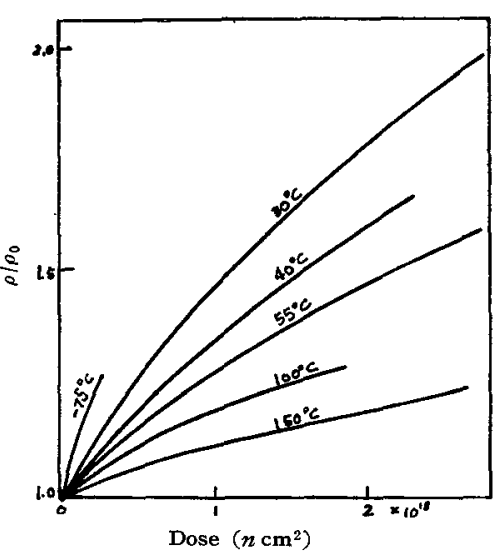

第 16 図種々の照射温度に竹 る電気抵抗の变化
の減少とが釣合う程度の少量の照射では，電気抵抗の増 加は格子欠陷の濃度に略々比例するけれども，自由電子 が殆どなくなる程の高度照射では正孔濃度の増加は平均 自由行路の減少と差引きになつて抵抗変化は飽和してし ま5。

種々の温度に於て照射を行つた場合の電気抵抗の変化 を第 16 図に示す ${ }^{(3)}$. 温度が高い程照射の影響が少い。

Hall 係数の照射による変化の温度による影響は，電 気抵抗の場合と似ているが，第 12 表でわかるよ 5 亿， $30^{\circ}$ 及び $150^{\circ}$ での照射で電気抵抗を同じだけ変化させ ても Hall 係数は両者で等しくならない，温度が異ると 格子欠陷の分布状態が違うか，格子欠陷の型が違らかの 何れかルよるものと考えられる。

第 12 表 照射を受けた黒鉛の Hall 係数(81)

\begin{tabular}{|c|c|c|c|c|c|}
\hline & & \multirow{2}{*}{$\rho / \rho_{0}$} & \multicolumn{3}{|c|}{ Hall 俬数 $\left(\mathrm{cm}^{3} /\right.$ coulomb $)$} \\
\hline & & & $300^{\circ} \mathrm{K}$ & $195^{\circ} \mathrm{K}$ & $77^{\circ} \mathrm{K}$ \\
\hline 照 & 前 & 1.00 & -0.060 & -0.083 & -0.155 \\
\hline $30^{\circ} \mathrm{C} \succ 0.9 \times 10^{18}$ & neutron $/ \mathrm{cm}^{2}$ & 1.44 & -0.018 & +0.021 & +0.202 \\
\hline $150^{\circ} \mathrm{C}$ で $6.3 \times 10^{18}$ & neutron $/ \mathrm{cm}^{2}$ & 1.44 & -0.005 & -0.012 & +0.116 \\
\hline
\end{tabular}

烧鈍による 電気抵抗の恢 復の様子を第 17 図化示す. これは順次高 い温度て $1 \mathrm{~h}$ ずつ焼鈍を行 つた結果であ る.照射の少 い場合は 400 ${ }^{\circ} \mathrm{C}$ ま゙急速 恢復が進 み, 400 1000 ${ }^{\circ} \mathrm{C}$ て更飞僅

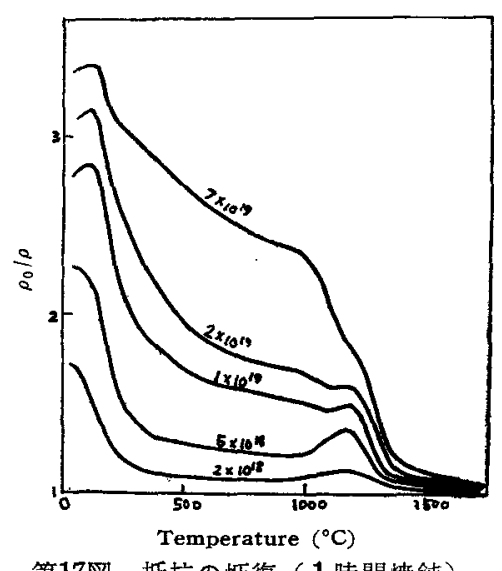

第17図 抵抗の恢復（1時間焼鈍）
か湾化する.恢復過程の活 性化エネルギーは $200^{\circ} \mathrm{C} ま$ で $1.2 \mathrm{eV}$ と得られ, $200^{\circ} \mathrm{C}$ 以上では急速に增大する。 照射量が多い場合飞は恢復は $1000^{\circ} \mathrm{C}$ まつづく.

第 16 挧で見るように $-75^{\circ} \mathrm{C}$ 以上では障害は新たに 生ずると同時恢復を起している. 及1 個 1 個の高速中 性子の衙突で生ずる障害の各領域は別々に恢復してゆく ように想像される。そうであるならば，或瞬間に生じた 抵抗変化 $d \rho$ が温度 $T$ 飞於て $t$ 時間後に $d \rho F(T, t)$ まで恢復したとすると，目数 $F(T, t)$ は低温で照射し た試料を焼鈍する実験で求め得る等である・障害が一定 の制合で生じ恢復が起らぬとして抵抗変化の速度 $d \rho / d t$ が与えられたとすれば, 温度 $T て ゙$ 時間 $t_{1}$ だけ照射され た場合の変化は次式で示される.

$$
\Delta \rho=\frac{d \rho}{d t} \int_{0}^{t_{1}} F\left(T, t_{1}-t\right) d t
$$

(4-1) 式を用いて低照射の焼鈍データから計算した曲 線は第 16 図の曲線とよく一致する(80).

$5 \cdot 2$ 熱后学度 普通测定する熱的性筫といえば熱

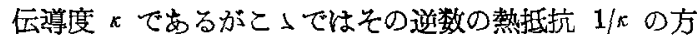
が噫味がある.第 18 図は縦軸に熱抵抗を横軸沉照射量

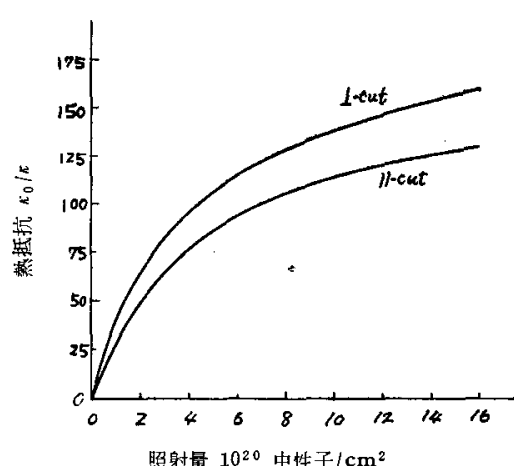

照射量 $10^{20}$ 中性子 $/ \mathrm{cm}^{2}$ をとつて変化 の有様を示し たものであ る。僅かの照 射でも熱抵抗 注急激に増加 する・これは 単独僈入原子 密度の增加を 示するのて， 更に照射を続

第 18 図 照射による熱抵抗の変化けると飽和す るが，な拓空孔と侵入原子群の蓄皘により緩やかな増加 を示している。

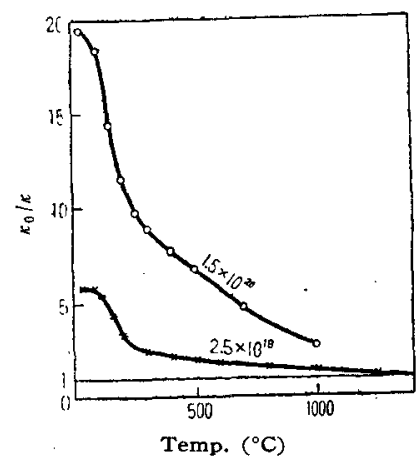

第 19 図 熱抵抗の恢復 $(2 \mathrm{~h}$ 焼鈍 $)$

熱抵抗の恢復の状 況を第 19 図に示す。 同一武料について電 気抵抗と熱抵抗のそ れぞれの恢復につい て求めた活性化工ネ ルギーは実験誤差 の範囲内で一致す

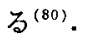

\section{5 -3 結晶構造}

黒鉛結晶は照射を 無定形炭素の方へ逆戻りしてゆく.格子の乱れは風間隔 $c_{0}$ の増大と層面の原子間距離 $a_{0}$ の収縮となつて現わ 


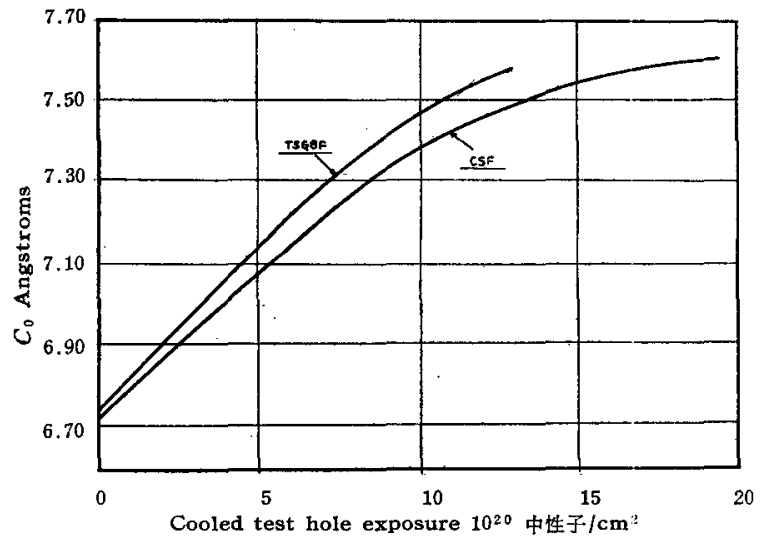

第 20 図 照射黒鉛の $C_{0}$ 変化

(TSGBF : Texas coke-GBF Process

( CSF : Cleves coke-Acheson Process

れる (第 20 図).

格子の乱れ愔炭素原子と入射エネルギー䊀子（特炕高

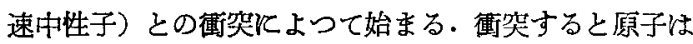
格子内の平衡位置から追出されその跡江空位が生ずる. 追い出された原子がその運動エネルギーを失つて半端な 処忓止るとそれる格子の乱れの因となる。

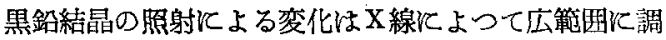
ベられている ${ }^{(79)(80) \cdot(002)}$ 备折線は照射の始期飞は小

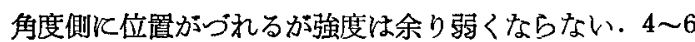
$\times 10^{20} \mathrm{n} / \mathrm{cm}^{2}$ の照射を受けると佪折線梳拉散してきて更 飞強い照射では全くぼやけてし东う・照射よる は，照射温度が高くなるとずつと少くなる. 第 21 図に 温度の影響を示す。

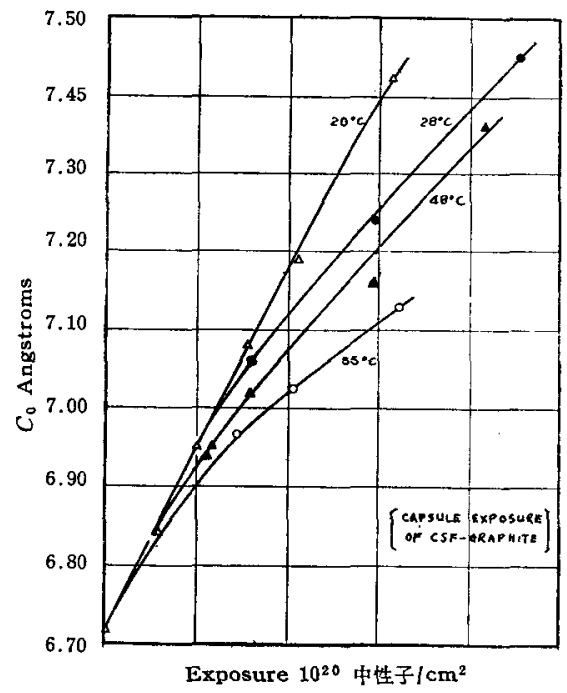

第 21 四 $C_{0}$ 変化飞対する温度影響 ${ }^{(3)}$

$a_{0}$ 変化はあ委り測られてないが照射によつて若习： $a_{0}$ が減る事が認められている(79)。

$c_{0}$ が掋がるのは照射によつて格子空位と半端な原子
点とができるためと考えられている、又 (002) のピーク が拡がるの結晶が壊れる中途の結晶面の菇みと过り のためであるう. $13 \times 10^{20} \mathrm{n} / \mathrm{cm}^{2}$ 位照射すると結晶は カーボンブラックや有機固体の熱分解物位まで崩れて しま5。

5.4 外形寸法 照射记上る寸法変化は，原子炬の 設計及び操作淤ける重要な関心事である。一般て黒 鉛材料は結晶方位 ( $c$ 軸) の方向飞伸び，直角方向飞 縮む頵向がある。しかし，この変化の程度は材料中の オリエンテーションの度合いによつて大幅に異る. 外 形寸法変化と結晶寸法変化とは定性的《関係がある程 度である.黒鉛は多孔質であるので外形寸法は結晶寸 法程大きな変化はしない。

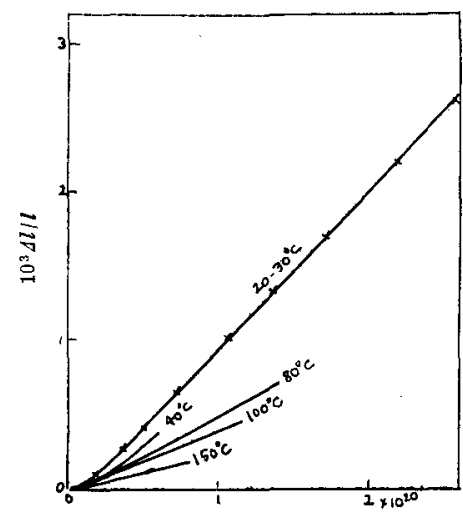

Dose $\left(n \mathrm{~cm}^{-2}\right)$

第 22 図種々の温度に挌ける押出 方向飞直角方向への照射 による寸法変化 ${ }^{(80)}$
外形寸法の見 掛の変化は 200 ${ }^{\circ} \mathrm{C}$ まて焼鈍して も少しも咴復せ ず，却つて夢る 少し膨脹が見ら れる. $200^{\circ} \mathrm{C}$ 以 上では恢復が起 る。第 22 図K 照射による形状 変化の例を示 于.

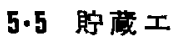
ネルギー、原 子昫中で照射を 受けると黒鉛結

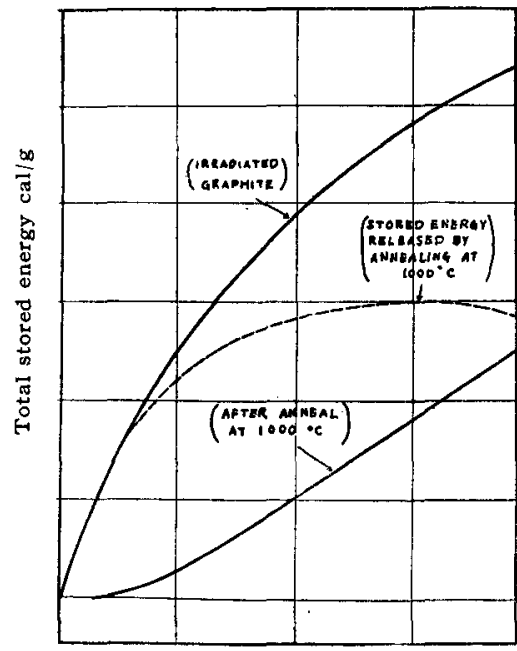

Cooled test holeexposure $10^{20}$ 中性子 $/ \mathrm{cm}^{2}$ 第 23 図中性子照射黒鉛飞的ける 全䝪蔵エネルギの生成
舀のエネル ギー含量は 增加する。 このエネル ギーの増加 を䠉藏エネ ルギー (stored energy）と呼 ぶ. 黑鉛試 料中の全貯 蔵エネルギ 一尗タ ルピーの増 加となつて 現れ，更比 然燒熱增 加する. 興
味のあるのほ全䠉蔵エネルギーの多少よりは, それが焼 
鈍によつてどう解故されるかという專である・第 23 図 は照射を受けた黒鉊の全䠉蔵エネルギーと，てれを1000

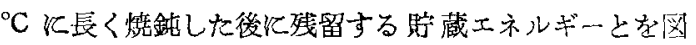
示したものである.両方の数值の差が烧鈍によつて解放 されたエネルギーで闵では破線で示されている。この場 合 $500 \mathrm{cal} / \mathrm{g}$ の貯蔵エネルギーは, $1 \mathrm{~g}$ の黒雓索 $1200^{\circ} \mathrm{C}$

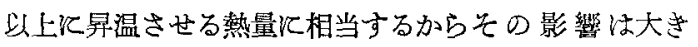
い. 貯蔵エネルギーは主として単独の侵入原子と空孔と

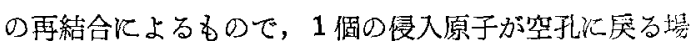
合住るエネルギーは約 $10 \mathrm{eV}$ と考允られている。

販蔵エネルギーの多宾は結鼠子の大きさの圂数であ る.結晶子の進んだ黒鉛程多量のエネルギーを吸收する。

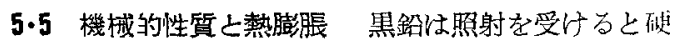

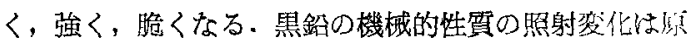
子炣操作江直接的な影響はあまりない，徒つて研究も岕 まり多くない，第 24 四からとの概貌を覣うことが出赇 ×5.

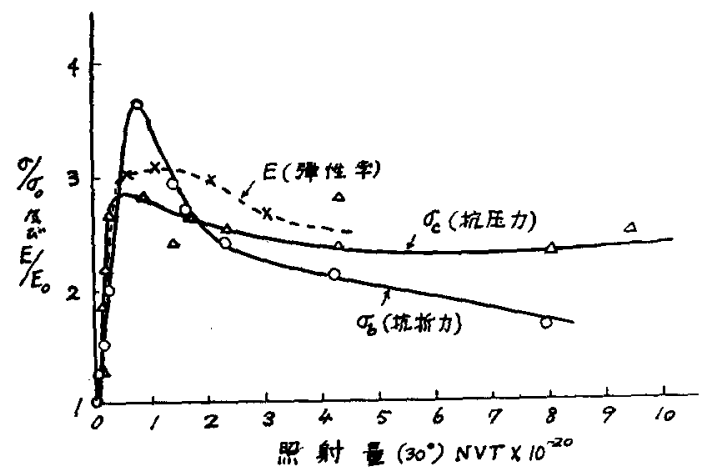

第 24 図 黒鉛の機械的性質の照射変化 ${ }^{(3)}$

原子炏用墨鉛の熱腿脹の盜度係数に対する照身の影響 は無視してよい. 埶膨脤係数は $30^{\circ} \mathrm{C} て ゙ 10^{20}$ 中性〕の 照射をして85 \%しか堌えない。

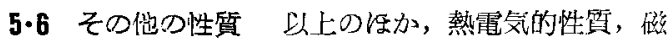
気的性望或比熱等について相当隹研究が行われてい 号、とれ等の性質は原子炸使用するに当つてはあまり 重要でなないが，故射線障害の機構を理論的に解明する 為には重要な手薄りになる。然しこっでは触れない。

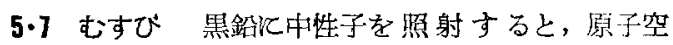
孔，単独侵入原子，侵入原子群の3 種の欠樎が生ずるす のと考えられ，物理的性質が大きく変化する。技術的見 地加ら注目すべきことは，機械的強度が 2 倍になると熱 伝導率が $1 / 5$ になること，3\%以上の直線的膨脹をする こと， $500 \mathrm{cal} / \mathrm{g}$ 以上の尉藏エネルギーを䀧える事であ つて，人造黒鈶 (アチソン黒鉛）に $30^{\circ} \mathrm{C} て 2 \times 10^{\circ 1}$ 中 性子 $/ \mathrm{cm}^{2}$ 程度の照射子与えた場合飞その程度になる。

これ等の変化は焼鈍によつて恢復するが，完全に元に 庆すには $2000^{\circ} \mathrm{C}$ 以上小㧈熱が必要である。製造条作飞

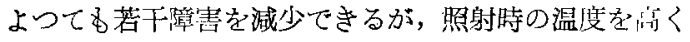

する方が有効である。

黑鉛の放射線照射障害の機構を完全に解明するに合 日の固体物理学では充分でない，䨘気抵抗，X線迴折，

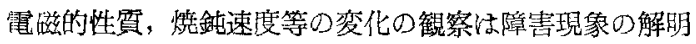

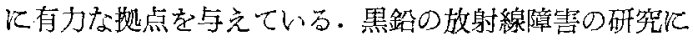
よつて得た知識は，原子力ェネルギーの発薏にとつて重 要な収獲となるであるう。

\section{6. 結言}

原子才工業はその国の凡ゆる関連工業の技衍を基底と して成立つものである。原子炻材料の一つである黒鉛の 品質について子非常に㸃度の要求がなされる事は上の解 説にも路かであつて，てれ等の解決飞多大の努力が必 要であり，我国の原子力工業の開拓は決して容易な業で に泳い，幸に黑鉊の正体については，兹数年の間に物性

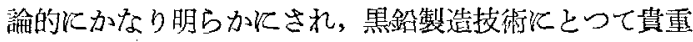

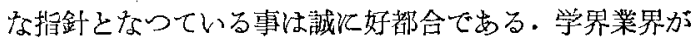
相娧力して新分野の発展伤努められんことを祈つてやま ない。

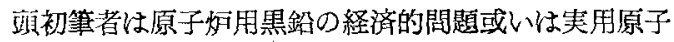

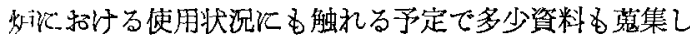
たが，これ等の問題については他澄表 ${ }^{(13)(83)}$ ああり，

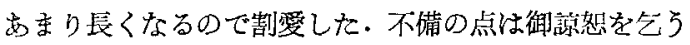
次第である.

終飞本稿忙当社栗原康雄，日野光雄両氏等の交献，資 料の䈭集，調查に負うところが多い。記して感謝の意子 表したい。

(昭 31-2-15 受理)

文献 (1) (18) 1 1 月月号揭载

(19) G.E. Bacon: Acta Cryst., 3, 137 (1950)

(20) G.E. Bacon: ibid, 4, 558 (1951)

(21) H. Lipson, A.R. Stokes: Proc. Roy. Soc., A 181, 277 (1942)

(22) J.P. Bernal : ibid., A 106, 749 (1924)

(23) P. Debye, P. Scherrer: Phys. Z., 8, 291 (1917)

(24) J. Biscoe, B.E. Warren: J. App. Phys., 13, 364 (1942)

(25) U. Hofmann, D. Wilm: Z. Elektroch., 42, 504 (1936)

(26) R.E. Franklin: Acta. Cryst., 4, 253 (1951)

(27) J.S. Lukesh: I. Chem. Phys., 19, 1203 (1951)

(28) L. Brewer, P. Gilles, F. Jenkins: $I$. Phys. Chem., 16, 797 (1948); O. Simpson, R. Thorne, G. Winslow: Arg onne Nat. Lab. Reb., No. 4264 (1949); A.L. Marshall, F.T. Norton: I. Am. Chem. Soc., 72, 2166 (1950); M. Hoch, P.E. Blackburn, D.P. Dinglady : J. Phys. Chem., 59, 97 (1955); W.A. Chupka, M.G. Inghram: J. Phys. Chem., 59, 100 (1955)

(29) A.L. Marshall, F.T. Norton: I.A.C.S., 55, 431 (1933); J. Basset : Brennst.Ch., 23, 127 (1942)

(30) N.K. Chaney, V.C. Hamister, S.W. Glass: Trans. El. ectrochem. Soc, 67, 107 (1935); J. Basset: J. Phys. Ra dium, 10, 217 (1939)

(31) A. Magnus : Ann. Phys., 70, 303 (1922); M.H. Spencer: I.E.C., 40, 2152 (1948)

(32) W. DeSorbo, w. Tyler: J. Chem. Phys., 21, 1660 (1933)

(33) P.H. Keesom, N. Pearlman: Phys. Rev., 99, 1119 (1955)

(34) J. Krumhansl, H. Brooks : J. Chem. Phys., 21, 1663(1953)

(35) K. Komatsu, T. Nagamiya: J. Phys. Sac. Jap., 6, 438 (1951); T. Nagamiya, K. Komatsu: J. Chem. Phys., 22, 1457 (1954); K. Komatsu : J. Phys. Soc. Jap., 18, 346 
(1955)

(36) P.R. Wallace: Phys. Rev., 71, 622 (1947)

(37) C.A. Coulson: Nature, 159, 265 (1947); C.A. Coulson, R. Taylor: Proc. Roy. Soc. (Edinburgh), 62 A, 336, 350 (1947) ; Proc. Phys. Soc. (London), 65 A, 815 (1952

(38) J.B. Barriol, J. Metzger : $J$. Chem. Phys., 18, 432, (1950)

(39) J.A. Krumhans1, J. Carter: Y. Chem. Phys., 21, 2238 (1953)

(40) S. Mrozowski : Phys. Rev., 85, 609 (1952); 86, 1056(1952)

(41) D. Johnston: Proc. Roy. Soc. (London) 227 A, 349 (1.955)

(42) W. Lomer : ibid., 227 A, 330 (1955)

(43) K.S. Krishnau, N. Ganguli : Nature, 144, 667 (1939);W. Primak, L. Fuchs: Bull. Ant. Phys. Sos., 27, 18 (1952); G.H. Kinchin: Proc. Roy. Soc. (London), 217 A,9 (1953)

(44) H.T. Pinnick: Rep. Res, Conf. on Phys. of Carbon, Baffalo Univ. (1953)

(45) E.E. Loebner: Phys. Rev., 84, 153 (1951); 86, 1056(-.952)

(46) E.A., Kmetko: J. Chom. Phys., 21 (1953)

(47) W.F.K. Wynne-Jones, H.S. Blaydon, R. Jley : Brennst.Ch., 73, 268 (1952)

(48) 浾松秀雄, 井口洋夫：学振 117 小委報 (1953)

(49) T. Pinnick: Phys. Rev., 91, 228 (1953)

(50) R.W. Powell, F.H. Schofield: Proc. Roy. Soc., 51, 153 (1939)

(51) R. Berman: Proc. Phys. Soc., 465, 1029 (1952)

(52) 水島三知: Phys. Rev., 86, 1040 (1952)

(53) W.W. Tyler, A.C. Wilson, Jr.: Phys. Rev., 89, 870(1953)

(54) A.W. Smith:Phys .Rey., 95, 1094 (1954)

(55) J.G. Castle, Jr.: Rept. Res. Conf. on Phys. of Carbons, Buffalo Univ. (1953)

(56) J.B. Nelson, D.R. Riley : Proc. Phys. Soc, 51, 477 (1945)

(57) S. Mrozowski : Rept. Res. Conf. on Phys. of Carhons, Buffalo Univ. (1953)

(58) P.L. Walker, Jr.: H.A. Makinstry, C.C. Wright: I.E.C., 45, 1711 (1953)

(59) R.Thorn, O.C. Simpson: J. Appl. Phys., 24, 633 (1953)

(60) R.H. Savage: I. Appl. Phys., 19 (1), 1-10 (1948); Ann.
N.Y. Acad. Sci., 53, 862 (1951)

(61) S. Mrozowski : Bull. Am. Phys. Soc., 21, (1) 47 (1952)

(62) C. Malmstrom, R. Keen, L. Green, Jr.: J. Appl. Phys., 22, 593 (1951); F.E. Faris, 'L. Green, Jr., C.A. Smith : ibid., 23, 89 (1952)

(63) M.S. Wright: Electroch. Soc. Monograph on High Te $m p$. (New York)

(64) W.E. Schwabe: Elektrowärme-Tech., 1, $6(1950)$

(65) H.E. Blaydon, H.L. Riley : J. Soc. Chem. Ind., (Lond.) 54, $159 \mathrm{~T}$ (1935)

(66) U. Hofmann : Ergeb. exaht. Naturw., 18,229 (1939)

(67) H.L. Riley: Fuel., 24, 8, 43 (1954)

(68) H. Thiele: Z. anorg. allgom. Ch., 206, 407 (1932)

(69) W. Rúdorff, U, Hofmann: Z. anorg. allgem. Ch., 238, 1 (1938)

(70) W. Rüdorff: Z. phys. Ch., 45 B, 42, 174 (1939)

(71) W. Riudorff : Z. anong. allgem. Ch.,245, 383 (1941)

(72) K. Fredenhagen, G. Cadenbach: Z. anorg. allg. Ch., 158,249 (1926)

（73）梁松秀雄，荻野一普：学振 117 小委報 117-1-17-1 (1951)

(74) 讳瀬元吉, J㥓政一：嵅素, 3，60 (1953)

(75) K. Fredenhagen, H. Suck: Z. anorg. allg. Ch., 178, 353 (1929)

(76) A. Schleede, M. Ziegler-Wellman: Z. phys. Ch., B 18, 1 (1932)

(77) R.N. Lyon (editor): Liquid-Metals Handb. (Washington), (1954)

(78) W. Rùdorff, H. Schulz: Z. anorg. allg. Ch., 245, 121 (1940)

(79) G.H. Kinchin: A/CONF. 8/P/442 U.K. (1955) July 1

(80) G.H. Kinchin: $J$. Nuclear Energy, 1, 124 (1954)

(81) P. Legendre, L. Mondet, Ph. Arragon, et al.: Rept. C.E.A. (France) $\mathrm{n}^{\circ} 424$

(82) R.E. Adams, H.R. Nelson: NEPA, BM1-N-45, May 1 (1950)

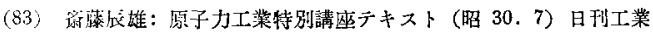

(84) G.R. Hennig: A/Conf. 8/P/751 (1955)

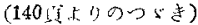

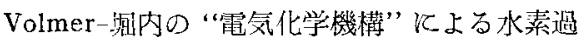
雷㞋の完全な理論 K.I. J. Vetter オッシログラフによるニッケル精銆の不可逆分 桠价究 I H. Fischer, M. Seipt,G. Morlock

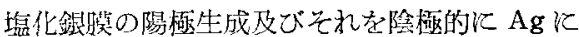

還元する時の現象

W. Jaenicke, 他 2

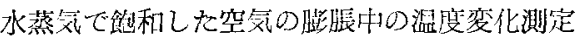

R. Manshart, M. Pollermann

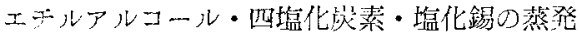

逽应 II. L. von Bogdandy, 他 2

$\mathrm{Ni} .6$

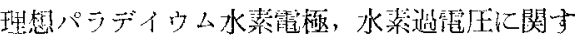

号問题 M.V. Stackelberg, H. Bischoff

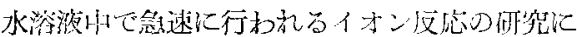

凉する㣫撃電位法 M. Eigen, J. Schoen

Randles-Sevčikchen 陰極線ボーラログラフ

○基詥

H. Matsuda, Y. Ayabe

强酸浴液中心硝于電桠の起電状態

狞隔塩について

P. Drossbach

フミン变塩行よる異常霍導

Fr. Halla, 他

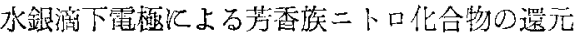

IV パラニトロベンゾールの置換について

H. Schmidt, L. Holleck 531
基㵀化合物中に於ける荷電振動及び 435

440

443

455

460

467

483

494

504

512

525

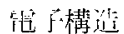

E. Lippert

534

ヘブタン・ベンゾール・ジオキサン中のジェ

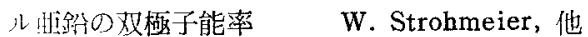
538

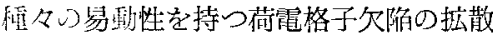

B. Ilschner

$\mathrm{K} . \mathrm{NiF}_{4}$ の棈造

D. Balz, K. Plieth

热機物の，イオン半径，分子届折，分極率，光痋折

について 1. ハロゲン化アルカリ E.Kordes

シリンダー法による磁気化学研究に於忛る強磁

性:做化率の效果及びその遗断について

A. Knappwost

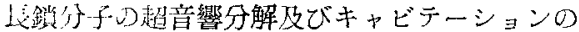

HI湓 II.

M. Okuyama

542

545

$1000^{\circ} \mathrm{C}$ 飞於故る鉄の酸化に対する酸素压の影

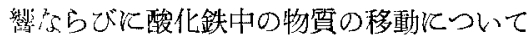

H. Pfeiffer u C. Lanbmeyer

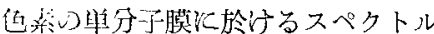

H. Käufer, G. Scheibe 584 